\title{
TTR
}

Traduction, terminologie, rédaction

\section{A Catholic Horace at the English Court: Paratextual Manipulations in Thomas Hawkins's Odes of Horace (1625-1638)}

\section{Marie-Alice Belle}

Volume 32, numéro 1, 1er semestre 2019

Traduction et politique(s)

Translation, Politics and Policies

URI : https://id.erudit.org/iderudit/1068013ar

DOI : https://doi.org/10.7202/1068013ar

\section{Aller au sommaire du numéro}

\section{Éditeur(s)}

Association canadienne de traductologie

ISSN

0835-8443 (imprimé)

1708-2188 (numérique)

Découvrir la revue

Citer cet article

Belle, M.-A. (2019). A Catholic Horace at the English Court: Paratextua Manipulations in Thomas Hawkins's Odes of Horace (1625-1638). TTR, 32(1), 17-46. https://doi.org/10.7202/1068013ar
Résumé de l'article

L'article examine les différentes modalités de l'appropriation de certaines Odes d'Horace par le traducteur Thomas Hawkins, actif dans les milieux de cour anglais sous le règne de Charles $\mathrm{I}^{\mathrm{er}}$ et Henriette-Marie (1625-1649), mais aussi dans les réseaux catholiques anglo-français de l'époque. On montre comment le traducteur inscrit ses prises de position culturelles, idéologiques et littéraires dans le paratexte des éditions successives du volume imprimé (1625-1638), en particulier dans la préface et les poèmes d'éloge composés par divers poètes de cour qui ouvrent le volume. L'étude revisite les méthodes fondatrices proposées par Theo Hermans (2014a [1985]) et André Lefevere (2006 [1992]) pour étudier la " manipulation de la renommée littéraire » dans l’Angleterre de la première modernité (voir aussi Lambert et Van Gorp, 2014 [1985] et Toury, 1995). Tout en confirmant l'importance de documenter les pratiques de mécénat et les normes culturelles en vigueur dans les milieux de cour, on montre ici qu'afin de saisir dans toute leur complexité les stratégies d'encodage idéologique et politique des traductions imprimées dans le contexte de l'époque, il convient d'adopter une démarche méthodologique plus "vaste » (" enlarged », Tymoczko, 2005, 2007). Il s'agit donc de compléter l'approche critique traditionnelle associant la manipulation littéraire à la logique du mécénat et des normes culturelles, en portant une attention renouvelée aux conditions matérielles de production et de circulation des oeuvres traduites; leur signification dans le contexte de tensions politiques et idéologiques à la cour des Stuart; et la place des traducteurs dans des réseaux d'appartenance sociale, politique et religieuse s'étendant bien au-delà de l'influence politique et littéraire de la cour.
Ce document est protégé par la loi sur le droit d'auteur. L’utilisation des services d’Érudit (y compris la reproduction) est assujettie à sa politique d'utilisation que vous pouvez consulter en ligne.

https://apropos.erudit.org/fr/usagers/politique-dutilisation/ 


\title{
A Catholic Horace at the English Court: Paratextual Manipulations in Thomas Hawkins's Odes of Horace (1625-1638)
}

\author{
Marie-Alice Belle \\ Université de Montréal
}

\begin{abstract}
This article addresses the ways in which Thomas Hawkins, a translator engaged in the cultural and literary activities of early Stuart court culture, but also in the transnational, Anglo-French Catholic networks of the time, appropriates certain Odes of Horace to assert his cultural, literary, and ideological values at the courts of Charles I and Henrietta Maria. Focusing in particular on the paratexts of the printed volume in its various editions (1625-1638), which include a translator's preface as well as a number of commendatory poems from contemporary writers and courtiers, this article revisits Theo Hermans's (2014a [1985]) and André Lefevere's (2006 [1992]) seminal methods for analyzing the 'manipulation of literary fame' in early modern England. While confirming Hermans's and Lefevere's attention to issues of patronage and cultural norms, as well as the pivotal importance of paratexts as markers of such factors, I argue that the strategies of ideological and political encoding at work in the productions of English seventeenth-century court culture are best understood when approached from an "enlarged" (Tymoczko, 2005, 2007) methodological stance. This means complementing well-established analyses of literary manipulation in terms of patronage and cultural norms with specific attention to the material conditions in which translations were produced and circulated; their significance to the complex and ideologically conflicted milieu of the early Stuart court; and the social, political, and religious networks in which translators operated, well beyond the immediate circles of courtly patronage and influence.
\end{abstract}

Keywords: translation, manipulation, cultural approach, historical network analysis, early modern England

Résumé

L'article examine les différentes modalités de l'appropriation de certaines Odes d'Horace par le traducteur Thomas Hawkins, actif dans les milieux de 
cour anglais sous le règne de Charles I ${ }^{\text {er }}$ et Henriette-Marie (1625-1649), mais aussi dans les réseaux catholiques anglo-français de l'époque. On montre comment le traducteur inscrit ses prises de position culturelles, idéologiques et littéraires dans le paratexte des éditions successives du volume imprimé (1625-1638), en particulier dans la préface et les poèmes d'éloge composés par divers poètes de cour qui ouvrent le volume. L'étude revisite les méthodes fondatrices proposées par Theo Hermans (2014a [1985]) et André Lefevere (2006 [1992]) pour étudier la «manipulation de la renommée littéraire» dans l'Angleterre de la première modernité (voir aussi Lambert et Van Gorp, 2014 [1985] et Toury, 1995). Tout en confirmant l'importance de documenter les pratiques de mécénat et les normes culturelles en vigueur dans les milieux de cour, on montre ici qu'afin de saisir dans toute leur complexité les stratégies d'encodage idéologique et politique des traductions imprimées dans le contexte de l'époque, il convient d'adopter une démarche méthodologique plus «vaste» («enlarged», Tymoczko, 2005, 2007). Il s'agit donc de compléter l'approche critique traditionnelle associant la manipulation littéraire à la logique du mécénat et des normes culturelles, en portant une attention renouvelée aux conditions matérielles de production et de circulation des œuvres traduites; leur signification dans le contexte de tensions politiques et idéologiques à la cour des Stuart; et la place des traducteurs dans des réseaux d'appartenance sociale, politique et religieuse s'étendant bien au-delà de l'influence politique et littéraire de la cour.

Mots-clés: traduction, manipulation, approche culturelle, analyse historique des réseaux, première modernité anglaise

It has been over thirty years since the publication of Theo Hermans's seminal collection of essays, The Manipulation of Literature: Studies in Literary Translation (1985; reprinted in 2014), which was to give its name to the "Manipulation School" of Translation Studies. This volume was soon to be followed by André Lefevere's no-less important monograph Translation, Rewriting, and the Manipulation of Literary Fame, published in 1992 (reprinted in 2016). Hermans was later to note that the expression "Manipulation School" was used as a bit of a joke (see on this Lambert, 2006 [1995], p. 106), and that the notion of "manipulation" should by no means be understood as a form of judgmental positioning from the scholars involved, since their research is firmly established in the descriptive branch of Translation Studies.

The main tenet of the "manipulation" approach is, to quote Hermans's provocative statement, that "all translation implies a degree of manipulation of a source text for a certain purpose" (2014a [1985], p.11). The general objective, to quote this time from Lefevere's articulation of the project, therefore consists in studying 
how "rewriters adapt, manipulate the originals they work with to some extent, usually to make them fit within the dominant, or one of the dominant ideological or poeticological models of their time" (2016 [1992], p.6); or again, how "the process of translating and rewriting works of literature manipulates them to ideological and artistic ends, so that the rewritten text can be given a new, sometimes subversive, historical or literary status" (ibid., back cover). I should note here that, just like "manipulation," the notion of "ideology" carries no normative judgment value. It simply designates the general system of cultural norms, beliefs, and constraints that govern social and political behavior in a given context-or, as Lefevere succinctly puts it, quoting Fredric Jameson, "that grillwork of form, convention, and belief which orders our actions" (in Lefevere, 2016 [1992], p. 16). Literary translations are thus to be approached as part of a broader phenomenon of literary "refraction" (Lefevere, 1984) in which texts are adapted, edited, transformed, re-framed-hence, manipulatedunder the influence of social norms, ideological needs, commercial pressures, and institutional power.

Although both Theo Hermans and José Lambert have claimed that the manipulations approach was not originally conceived of as a systematic or programmatic research programme (Hermans, 1999; Lambert, 2006 [1995]), it did come with a methodological model. This was outlined in great detail in the contribution to Hermans's 1985 Manipulation volume by Lambert himself and Hendrik Van Gorp, a piece revealingly entitled, "On Describing Translations," and reprinted twice since. Explicitly building on Gideon Toury's descriptive methodology, Lambert and Van Gorp present a four-pronged "synthetic scheme" designed to identify the various shifts at work in the translated, or rewritten, text, and to relate them with the complex literary and cultural systems in which both original and translation participate (see in particular 2014 [1985], pp. 50-53).

First, one is to conduct a "preliminary" study of the general translation strategy, as indicated by the translation's title, preface, etc., and by the general economy of the translated text-for example, if the rewritten text consists of a partial or complete translation (Lambert and Van Gorp, 2014 [1985], p. 52). Second, one is to describe the translated text at the "macro-level," noting its division into chapters, for example, and its internal narrative structure (ibid). The third step involves a "micro-level" examination of shifts at the linguistic, narrative, and discursive levels: the description is of course to interact 
with the findings in steps 1 and 2 (ibid., pp. 52-53). For example, if the title announces that the text is a free translation, and that obvious omissions have been observed, the analysis of shifts at the micro-level is naturally to be correlated to those findings. Finally, and perhaps most interestingly for us if we are to focus on the political and ideological manipulation of literary texts through translation, the fourth level of analysis requires that all previous findings be related to the "systemic context." This includes the theory and discourse on translation at the time; the literary, ideological (and one should add here, political) norms that may help explain the observed shifts; but also the potential intertextual links that exist between the translation under analysis and other literary texts, as well as the generic and stylistic codes engaged in the translated text as part of the broader literary system (ibid., p. 53).

The theoretical framework for this model was explicitly systemsbased, with both Itamar Even-Zohar and Gideon Toury cited as foundational influences (ibid., p. 43). Perhaps as a consequence, the methodology outlined by Lambert and Van Gorp became somewhat marginalized after Lefevere and others took the "cultural turn" in the 1990s (see on this Hermans, 1999, p. 14), and shifted the theoretical emphasis of the manipulation of literary texts from its original polysystems orientation towards a more specific interest in the influence of ideology, patronage, and institutions in the production of literary translations (see e.g., Lefevere, 2016 [1992]; Bassnett and Lefevere, 1990, 1998; Venuti, 2018 [1995]).

In this article, I shall revisit these seminal methods for analyzing the "manipulation of literary fame" to political and ideological ends, and examine how they help address an apparently minor, or at least, lesser-known product of translation activities in seventeenth-century English court circles. The case at hand is a partial translation of the Odes of Horace produced in 1625 by Thomas Hawkins (c. 1575-1640), a translator who was extremely active in English Catholic circles, especially around the courts of King Charles I (r. 1625-1649) and his consort, Queen Henrietta Maria. This case suggests that, even when extracted from their original polysystems-based framework, the methods first outlined by Hermans, Lambert, Van Gorp, and Lefevere still prove extremely efficient in order to describe and, to a certain extent, explain the ideological and political framing of literary translations in a specific historical and cultural context. Yet at a time when translation scholars are calling for an "enlargement" of theoretical and methodological scopes beyond established descriptive and 
cultural models (see e.g., Tymoczko, 2005, 2007), I shall also show how the case study may benefit from complementing the manipulation approach based on norms, patronage, and ideology, with an additional focus on the material features of the printed translation, and its place within the complex social and political networks of its times.

Since a full examination of the linguistic and poetic shifts enacted by Hawkins in his translation would far exceed the limits of a single article, I will concentrate on the preliminary, macro- and contextual levels, with a particular focus on the paratexts of the volume first printed in 1625 by the London stationer, William Lee. Following Gérard Genette and others, I consider here as paratexts the various liminal materials that surround translated texts, such as title pages, prefaces, dedications, encomia and other forms of commendatory pieces, translators' notes, etc. (Genette, 1987, 2001; on early modern paratexts, see in particular Saenger, 2006, and Smith and Wilson, 2011). While not always conceptualized as such, the liminal features of translated books play an extremely important role in the manipulation approach, as sketched in Hermans's seminal piece and in Lambert and Van Gorp's descriptive methodology. They also play a key part in Lefevere's and Bassnett's cultural approach. Lambert and Van Gorp include title pages, prefaces, footnotes and other "metatexts" in the preliminary description of translated texts; they also recommend considering chapter titles as part of the macrolevel analysis (2014 [1985], p. 52). Prefaces, dedications, and other liminal pieces similarly form the basis of Hermans's own contribution to the 1985 Manipulation volume, in which he traces a shift in English cultural norms and attitudes towards translation in the first half of the seventeenth century by examining the rhetoric of praise deployed in the liminal spaces of literary translations (Hermans, 2014b [1985]). For Bassnett and Lefevere, paratextual materials also represent important sources from which to infer translators' attitudes towards contemporary translation theories and cultural norms (see e.g., Bassnett, 1998, pp. 31-32; Lefevere, 1998, pp. 21-24 and 50-51). Lefevere equally highlights the importance of examining translators' prefaces and dedications, as well as that of the editorial framing of the translated text, if one is to re-construct the translation's relation to the system of power and patronage (e.g., Lefevere, 1984, p. 231).

The inclusion of paratextual material in the description and analysis of translations is, however, not limited to the manipulation or cultural approaches. In recent years, paratexts have been shown to 
represent extremely rich archival material in other socio-historical approaches to translation, literary or not (see Tahir-Gurçaglar, 2002; Bastin, 2010; Gil Bardaji et al., 2012; Pellat, 2013, among others). As Guyda Armstrong usefully summarizes:

The paratextual material which can accompany a text thus ranges from the factual, organizational, and ostensibly objective (e.g., the title, the author's name, the table of contents) to more discursive and more obviously subjective additions (e.g., dedications, author biographies, prefaces). Paratexts can even be non-textual, yet still highly meaningful (e.g., decorative elements such as illustrations). An analysis of the paratext can thus be an invaluable key to understanding the reception of a particular author by revealing contemporary perceptions of his or her status, as well as allowing us to draw tentative conclusions about historical readerships and reading patterns. (2007, pp. 40-41)

More specifically, as recent scholarship on translation and print practices in early modern Britain has demonstrated, the liminal features of the printed book are of particular importance in the early modern English history of translation (Armstrong, 2007, 2015; Coldiron, 2012, 2015a, 2015b; Hosington, 2017; Belle and Hosington, 2017, 2018). If the early modern period arguably represented a key moment in the crystallization of the English literary canon and cultural identity, this was also a time of intense literary, cultural, and ideological exchanges with continental Europe. The production and circulation of translations are witness to both cultural currents, and the material features of translated books have been shown to illustrate the tensions inherent to the fashioning of Britain's literary self in dynamic relation to the past and to the continental "other" (see in particular Coldiron, 2015a, Armstrong, 2015, Boro, 2018). In this complex cultural and historical context, the liminal spaces of printed translations open a space par excellence for textual, ideological, social and material negotiation-and hence, manipulation.

How are such tensions negotiated in the case of Hawkins's Horace translation? To start at the preliminary level of analysis, the front material of the 1625 Odes of Horace makes it clear that this is a literary project. The source is Horace's Odes, which was considered at the time as the major poetic model for lyric poetry, with a long tradition of translations and imitations into English (see e.g., Martindale, 1997; Scodel, 2010). The title page explicitly recognizes Horace as such, as it advertises: "Odes of Horace, the best of lyrick poets" (Hawkins, 1625, title page; see Figure 1). 


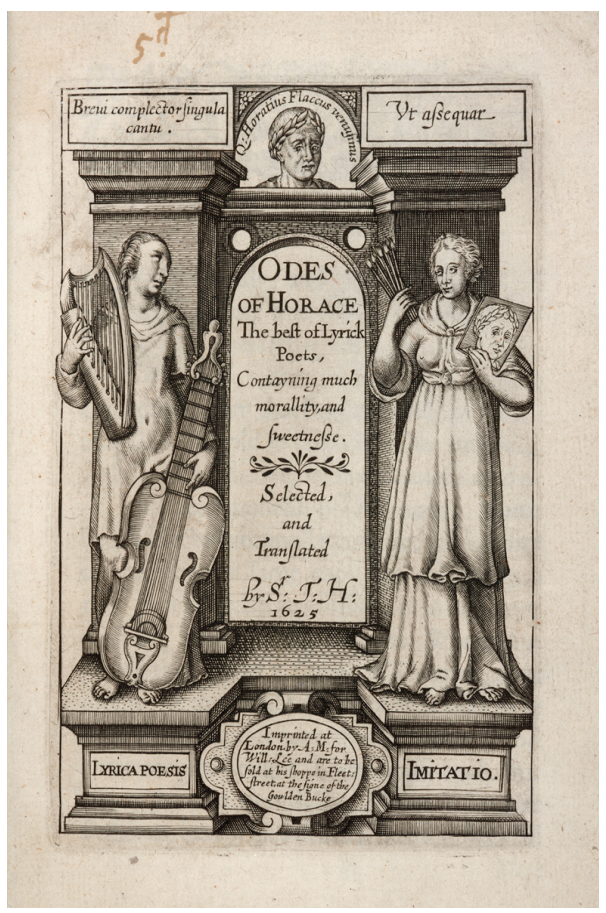

Figure 1. Odes of Horace, the best of Lyrick Poets [...] Selected and Translated by Sir T[homas] H[awkins]. London, A. M. for William Lee, 1625, title page. Reproduced by permission of The Huntington Library, San Marino, California, Shelf $n^{\circ}: 16966$.

The material features of the book are equally eloquent. The engraved title page acknowledges the authority of the Ancient poet by featuring his portrait in a medallion at the top of the page. The allegorical figures flanking the title on each side, that is, "lyrica poesis," holding a lyre, on the one side, and "imitatio," holding a mirror, on the other, advertise in turn the poetical ambition of the translation. The word imitatio is extremely important here, since Horace himself, in the famous "fidus interpres" passage of his Art of Poetry, had notoriously rejected "servile" translation, as other court translators were later to call it, in favour of "imitation" as a poetic, literary mode of rewriting (see most notably Denham, 1647, and analysis in Venuti, 1995, pp. 44-50). Hawkins himself declares in his preface that he has "in this Translation, rather sought [Horace's] Spirit, th[a]n Numbers [i.e. the original choice of meter and diction]" (Hawkins, 1625, sig. Ar). 
In practice, he adopts the English form of the rhymed couplet, which at the time was becoming the standard for verse translations of the Classics. He also appears to be striving for both clarity and ease of diction, as demonstrated in the following passage translated from Ode 1.31 (“To Apollo," pp. 10-11):

... O (great Apollo) grant,

To me in health, and free from lifes annoy,

Things native, and soone gotten to enjoy;

And with a mind compos'd old age attaine,

Not lothsome, nor depriv'd of Lyrick straine. ${ }^{1}$

To go back to the title page, the translation presents itself from the outset as doubly validated by Horace's authority, both at the iconic level (with Horace's portrait and the allegorical figures) and at the discursive level ("best of lyric poets," "poesis," imitatio"). This strategy achieves from the start, not only a manipulation of Horace's literary fame, but also, more precisely, a transfer of his cultural capital, as Lefevere, calling upon Bourdieu, was also to call such practices (Lefevere, 1998). While the translator remains unnamed on the title page (only the initials, T. H., are apparent), his work is fully invested from the start with Horace's cultural auctoritas as a Classical poet, here portrayed as an unchallenged master of lyric poetry, and, quite importantly, as the dominant model for literary translation practices.

Still at the liminal stage, we can equally observe that Horace is not only presented as a literary authority, but also as a source of moral instruction: the subtitle displayed on the title page announces that the Odes "contain $[\ldots]$ much morality and sweetness." Here again, the undertext is fully Horatian, since the phrase echoes Horace's no-less hackneyed commonplace, also taken from the Art of Poetry, in praise of poets whose verse is both profitable and pleasant. The verse "omne tulit punctum qui miscuit utile dulci" ("he always takes the prize, who mixes the useful with the pleasant"), which is perhaps one of the most widespread quotations in early modern prefaces and title pages, also proliferated in various forms in the paratexts of translations in the period (see on this Belle, 2017a, pp. 76-77). Here, of course, Hawkins takes full advantage of the commonplace, since he applies it directly to its original author while at the same time using it to guarantee the moral value of his own translated work.

1. The Latin reads: "Frui paratis et valido mihi,/Latoe, dones, at, precor, integra/cum mente, nec turpem senectam/degere nec cithara carentem." 
As we turn the page and cross the threshold into the book, we find the idea of Horace as a moral poet at the very forefront of the "Translator's address to the Reader," in which Hawkins declares: "Behold in them [i.e., the translated odes] morality touched, and Vertue heightened, with clearenesse of Spirit, and accuratenesse of Iudgment." Hawkins further explains that the selection announced on the title page ("Selected and translated") has been made on the basis of such moral criteria. Comparing his choice to the picking of flowers for a garland, Hawkins denies at first that he should ever want to impose his own values on others: "These have I selected amongst many, not with desire to prescribe the same choice to others, as a rule" (sig. Ar). Yet he does adopt a moral high ground when noting:

Some will urge againe, why were not these Wreathes of morall, and serious Odes, for the more varietie, and general entertainment of most, mixed with his wanton and looser straines of Poesie? [...] The Translatour of these had rather teach Vertue to the modest, th[a]n discover Vice to the dissolute [...] Drinke thou goodnesse from these purer Fountaines, whilest such take unhappy draughts, from the troubled and muddy waters of Sensuality (sig. Av).

If we jump over the remaining front matter for a moment, and look at the selection itself (in keeping with the macro-level of analysis in Lambert and Van Gorp's model), we find that some odes that would have been familiar to the early modern reader have indeed been left out. The most striking omission is that of the famous carpe diem Ode 1.11, which would be included, for example, in the collection of All the Odes and Epodes by Henry Rider published in 1638 ("Be wise, and rack thy wines up, and quite breake/Thy long hope off in short space: while we speake,/Envious time flyes: lay hold upon this day,/Trusting the next as little as you may." Rider, 1638, p. 12). Also missing are pieces on homoerotic themes, such as Odes 1 and 10 of the fourth book, in which the speaking persona explicitly expresses his love for a young man - a topic that may have seemed unpalatable to the Catholic translator, perhaps on moral grounds, and more certainly for political reasons. The last years of James I's reign directly preceding the publication of Hawkins's translation were marked by sustained rumours (and libelous publications, see Bellany, 2002, pp. 254-261) about the King's scandalous relationship with his favourite, the Duke of Buckingham. After the death of James I and Charles I's accession to the throne in 1625, Buckingham remained a major political figure and literary patron at court (see more on this below) until his impeachment 
in 1626. At the time of publication of Hawkins's translation, then, the homoerotic odes did not only clash with his virtuous translation programme; they were also extremely sensitive politically.

\section{The fecond Booke. \\ Our Conftellations bothagree \\ In admirable fort. And thee lowes radiant lufice, hath exempt, \\ From Saturnes Beame maleuolent, And flack'd the wings of fpeedy death; What time the people with lowd breath, Thrice in the Theater did found That gladforme newes : Eu'n then a wound, By a tree's fall, my skull had broke. \\ But Woód-god $F$ aunus, from the ftroke, Mee then did happily affift, \\ (Patron of each Mercurialift.) \\ Then pay thy vowes, thy Temple build, \\ And I a tender Lambe will yeeld.}

Ode XVIII.

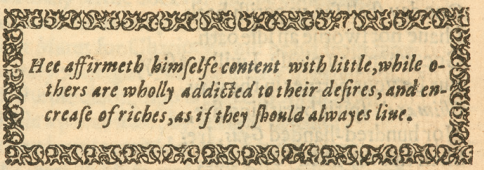

Non ebur, neque sureuss.

No guilded roofe, nor luory fiet, For fplendor in my boufe is fet;
The fecond Booke.

Nor beames are from $H$ ysettis fought, Tolye athwart rich Columnes, brought From Affrick; nor an heyre vnknowne, Atsalus wealth, make I mine owne. No honeft Clyents wiues you fee, Laconias Purples weare for mce: A loyall heart, and gentle vaine, Of wit I haue; which doth conftraine Rome's richeft men, to feeke the loue, of mee but poore: Nor godsaboue, Doe I inuoke for larger ftore; Nor of Macenas aske I more. Tomee, my onely sabize field, Sufficient happineffe doth yeeld. "One day thruft's on another faft, And new Moones to the Wane doe haft. When death (perhaps) is neare at hand, Thou fayrett Marbles doft command Be cut for vfe, yet doft negleet Thy graue, and houfes fill ereet, And would'ft abridge, the vaft Sea's thore, Which loudly doth at Baia rore: Enrichedlittle, lefle content, With limits of the Continent. Why ofren pullyou vp your bounds, T'enlarge the Circuit of your grounds, And grecdily your lift extend Beyond your neighbour fraightly penn'd? Both man, and wife with fordidbrood, And ancicnt boufhold gods, that food E2

27

Nor

Figure 2. Odes of Horace, the best of Lyrick Poets [...] Selected and Translated by Sir T[homas] H[awkins]. London, A. M. for William Lee, 1625, pp. 2627. Reproduced by permission of The Huntington Library, San Marino, California, Shelf $n^{\circ}: 16966$.

Another notable feature is Hawkins's treatment of Ode 3.9, which presents itself as a dialogue between two former lovers playfully evoking their past unfaithfulness, and renewed attraction, to one another. According to the Oxford History of Literary Translation into English, this was the most frequently translated ode of the seventeenth century (Scodel, 2010, p. 214). It is indeed included in Hawkins's volume, but with an apologetic note from the translator who defers to the authority of the famous Catholic Humanist critic, Julius Caesar Scaliger, to justify his choice: "this Ode, though lesse moral than the rest, I have admitted for Jul. Scaliger's sake, who much admireth it" (Hawkins, 1625, p. 38; see also Scodel, 2010, p. 215). 
The odes translated by Hawkins are in fact all introduced by a short abstract, or argument, often in a tone that echoes the moralistic posture of the preface. See, for example, as an introduction to Ode 2.18: "He [Horace] affirmeth himself content with little, while others are wholly addicted to their desires and increase of riches, as if they should always live" (Hawkins, 1625, p. 26). Here again, the material layout of the page is extremely important: the decorative frieze clearly sets aside the moral lesson of the ode, which is again confirmed by the first Latin line of the poem inserted just below the argument, and set in italics, like a motto: "Non ebur, neque aureum" ("neither ivory nor gold," ibid.). These paratextual features match Hawkins's translation practices: he often uses the rhymed couplet in a way that helps isolate moral sententiae, or short passages of a didactic kind. One salient example may be found in Ode 1.34, with Hawkins rendering Horace's complex syntax and verse pattern with a clear-cut couplet on Fortune's fickleness: "Hence restlesse Fortune, height from one man takes,/ With shrillest noise, and great another makes" “To himself," p. 12). ${ }^{2}$ We thus clearly have both Horace and his translator "teaching Virtue to the modest," as Hawkins self-righteously declares in his preface (sig. Av). It is highly significant, then, that in this same preface, Hawkins should frame his translation as only fit for the happy fewor rather, the virtuous few. His readers are carefully set aside from the common crowd looking for "general entertainment" and content with the "murky waters of sensuality" (sig. Av). This elitist attitude is again a Horatian posture: another famous and oft-quoted passage of the Odes at the time is the opening of Ode 3.1, "Odi profanum vulgus et arceo," here suggestively translated as: "I hate, and from mee do exclude/The most illiterate Multitude" (p. 29).

To go back to the liminal pieces preceding the poems themselves, one should note that the framing of the translation as a learned, refined piece of work had already been announced by the six laudatory poems composed by self-described "friends" of the translator and inserted between Hawkins's own preface and the translated odes. Half of them are in Latin-which does indeed "exclude the most illiterate multitude" - and composed in imitation of various Horatian verse forms. One is explicitly identified as "an Ode in pure Iambick feet" (sig. A3v), and another even comes with erudite marginalia (sig. A4r) mimicking contemporary editions of Horace's works. While

2. The original reads as follows: "hinc apicem rapax/Fortuna cum stridore acuto/ sustulit, hic posuisse gaudet." 
Hawkins had-modestie oblige-presented his work as but a pale reflection of Horace's poetry, his various friends celebrate him instead as "fidelissimus" ("most faithful," sig. A2r), "Horatius Anglus" ("the English Horace," ibid.), in skill an "equal" to the ancient master (sigs. $\mathrm{A} 2 \mathrm{v}$ and $\mathrm{A} 3 \mathrm{r}$ ).

Among those poems in praise of Hawkins, the English Horace one deserves particular attention - and with it I will move to the contextual level of analysis. This is the stage where (to follow Lambert and Van Gorp's methodology) we are to situate the translation in relation to the broader literary system, including previous translations. That is precisely what this poem does. The author, Hugh Holland, himself an established court poet, sets off to compare Hawkins's translation to the whole English tradition of Horatian poets, including (as the marginal notes additionally point out, see Figure 3) the famous poets Geoffrey Chaucer and Sir Philip Sidney, and ending with a most famous contemporary, Ben Jonson: "Thou hast reserved a part/To rouse my Jonson, and his Art" (sig. A3v). What Holland seems to mean here is that Hawkins's translation is so good that it cannot but attract the attention of - and perhaps even alarm ("rouse")?-Jonson, who, by his translations and imitations of Horace's poems (including a version of Horace's Art of Poetry that would be published posthumously in 1640), had already claimed for himself the title of "the English Horace" (see on this Pierce, 1981; Steggle, 1999; and Moul, 2010).

We could certainly read the inclusion of Holland's piece in terms of Lefevere's and Venuti's analyses of retranslations as texts that are competitive by nature, and that sometimes aggressively advertise their added cultural value by positioning themselves in relation to precedents (Lefevere, 1998; Venuti, 2004; see also Belle, 2014). Here, the mentions of Chaucer, Sidney, and Jonson help locate Hawkins within a genealogy of English translators and imitators of Horace's works, whose famous names eclipse those of other contemporary translators. Notably enough, in 1621, the young poet and scholar John Ashmore had already published a volume of Certain Odes of Horace, in a similar format including moral sententiae et various laudatory pieces by contemporary court poets (see Scodel, 2010, p. 216 and analysis in Belle, $2017 \mathrm{~b}$ ) - but it is not mentioned here.

That being said, Holland's naming of Jonson has a peculiarly intimate ring to it: by mentioning "my Jonson and his Arte," Holland alludes at once to his long-time friendship with the poet laureate and to Jonson's translation of Horace's Art of Poetry, which at the time 
had not been published, only circulating in manuscript form among Jonson's highly exclusive poetic circle (see Moul, 2010, pp. 177-178). What is traded here, then, is social as well as cultural capital. By comparing the published, translated odes with the manuscript translations circulating between Jonson and his friends, Holland symbolically includes Hawkins in the select, Horatian community of the "sons of Ben," a literary coterie that also included a number of high-ranking aristocrats: note that Holland addresses his poem to his "Noble Friend, Sir T. H., Knight" (sig. A3v; emphasis mine).

\begin{tabular}{|c|c|}
\hline 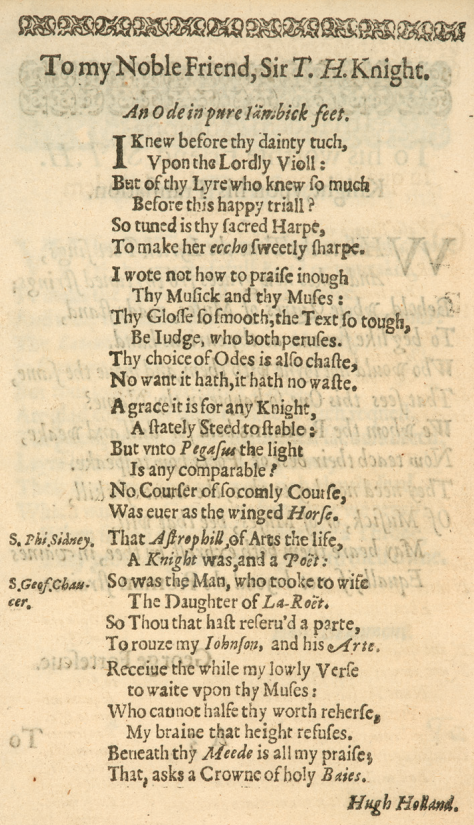 & 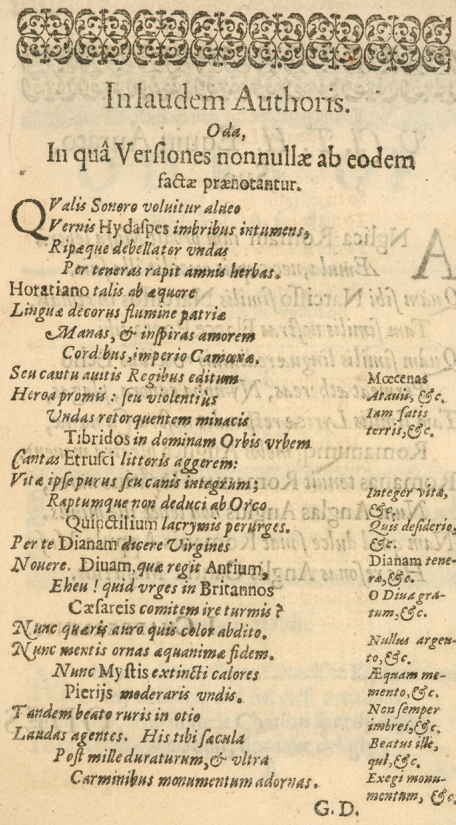 \\
\hline
\end{tabular}

Figure 3. Odes of Horace, the best of Lyrick Poets [...] Selected and Translated by Sir T[homas] H[awkins]. London, A. M. for William Lee, 1625, sig. A3v. Reproduced by permission of The Huntington Library, San Marino, California, Shelf $n^{\circ}: 16966$.

Another significant characteristic of the Jonson circle was its connection with the English Catholic, or recusant, community. Indeed, the authors of the liminal poems in Hawkins's 1625 volume (at least those who can be identified) all belonged, at some point or another, to Catholic court circles under James I and Charles I. Hugh Holland, 
who had enjoyed the patronage of the Duke of Buckingham, James I's favourite and still an influential figure in the early years of Charles I's reign, was a Catholic until April 1626, when he "submitted to the national church after having been indicted for recusancy" (Burrow, 2004). The author of the sonnet "To the Translator" (sig. A2v), John Beaumont, also a protégé of Buckingham, and whose poetic production until 1625 included verses dedicated to the future king, Charles I, similarly came from an old Catholic family. According to the Oxford Dictionary of National Biography $(O D N B)$, the Beaumonts belonged "to a whole chain of Catholic families which, with its own secret priesthood, extended [...] through all the ranks of nearby aristocracy and gentry" (Sell, 2004). His wife, Elizabeth Fortescue, was known to have harboured Catholic priests (ibid.). Another of the liminary authors in the 1625 volume is George Fortescue, Elizabeth's brother, who was educated at the English Jesuit colleges in Douai and Rome before pursuing a poetic and diplomatic career as the duke of Lorraine's ambassador to Pope Urban VIII (Kennedy, 2004). The ODNB identifies him as an "adamant Catholic," and part of an English "circle of Counter-Reformation writers" that also included Beaumont and Hawkins. Finally, while John Chapperlain, who signs the last laudatory poem in Latin, does not have an entry in the $O D N B$, he could perhaps be connected to the "Chapperlaine" mentioned in the "examination" for recusancy of the English Jesuit priest Thomas Strange held in 1606 at the Tower of London (Foley, 1878, p.14). He may also have been the "Mr. Chaperlin" identified as a "zealous Catholic" by the daughter of another staunch recusant and fellow translator at the early Stuart court, Lady Elizabeth Cary, in her biography composed in the 1640s (see Cary, 1994 [1613], p. 241)

This Catholic connection might not be surprising given the prominence of the Hawkins family among English recusants. The Hawkinses were an old Catholic family, particularly active in the underground network to which Fortescue, Beaumont, and, probably, Chapperlain, were all connected. Thomas Hawkins's brother, Henry, was an important figure in the English Jesuit community. He was ordained a Jesuit priest in 1615, and spent the rest of his life navigating between the English Jesuit colleges established on the Continent and the underground English Catholic community. He translated many works of Counter-Reformation literature into English (lives of saints, devotional writings, etc.), and thus made a significant contribution to the body of Catholic texts published by the English Jesuit presses 
at Rouen, Douai and St Omer, to the ends of being smuggled into England for the edification of recusant readers (Ryan, 2004). Thomas Hawkins himself would be indicted for recusancy and for harbouring Catholic priests in 1626, that is, the year directly following that of the Horace publication (Adolph, 2004). Although, again, Hawkins's name is not mentioned in full in the volume (the laudatory poems, like the title page, mention him only by his initials, T. H.), the names of his "friends" in the liminal pages of the translation make its connection with Catholic court circles highly visible to readers attuned to the religious politics of the early Stuart court.

The year 1625 was in fact of great portent in that respect, since it marked not only the accession of Charles I to the English throne, but also his marriage to the Catholic French princess, Henrietta Maria, sister to the French king Louis XIII. After the failure of the so-called Spanish Match, which was to unite Charles with the Spanish Infanta but ended in disappointment in 1623, the new king's marriage to Henrietta Maria raised great hopes for religious toleration towards Catholics in England. It appears that a secret clause was even included in the marriage contract to that effect (Solt, 1990, p. 167). Such expectations of future leniency towards English Catholicsespecially at Court-may have had some bearing on Hawkins's (and/or the London stationer, William Lee's) decision to publish. According to the Register of the Stationers' Company of London, which recorded all applications to publish made at the time, the title, clearly mentioning Thomas Hawkins as the translator, this time, was entered by Lee on May 27, 1625 (Arber, 1877, p. 103). This was shortly after Charles's marriage by proxy, which was performed in Paris on May 1 (or May 11, according to the French calendar) ${ }^{3}$, and was duly celebrated in England. Significantly enough, the Stationers' Register's records for May 14 (English calendar) include an entry for a volume to be published in French by Humphrey Lownes, Le Triomphe glorieux et l'ordre des ceremonyes observees au Mariage du roy de grande Britagne et de madame soeur du Roy (Arber, 1877, p. 102). The royal couple was to be married in person at Westminster in June of that same year. It appears, then, that the publication of the Horace translation was planned at a time when recusant connections could possibly be safely

3. Catholic countries such as France had adopted the Gregorian calendar in 1582, while England continued to go by the Julian calendar until 1752, which results in a 10-day gap between French and English dates for our period. French sources thus give May 11 as the date of the marriage by proxy. 
displayed, and when a volume clearly emanating from the Catholic party at the English court was likely to enjoy a favourable reception.

The participation of Catholic courtiers and poets in the liminal pages of the translation also proves crucial when it comes to interpreting Hawkins's moralizing stance, as well as his exclusive strategies both at the textual level (i.e., his choice of odes) and at the discursive level (i.e., his positioning against "others"). As noted above, the portrayal of Horace as a "moral" poet was nothing new. Adding an introductory "argument" to translated poems was also customary in early modern editions and translations of Horace-and some of them adopted an equally didactic tone (see on this Scodel, 2010, p. 214). However, it seems that, when attacking those who enjoyed the "loose or wanton" strains of Horace's poetry, Hawkins has a particular target in mind. If the 1620s and 1630s were a golden age of Horatian translation, the "Horace of Ben Jonson and his heirs" (Martindale, 1997), was also — and increasingly so - the epicurean Horace of the carpe diem. For court poets such as Robert Herrick, for example, the Horatian precedent offered an occasion to explore a wanton vein characterized by both sensual themes and elaborate metrical patterns. Herrick's version of Ode 3.9, in particular, which was to be set to music in 1627 , enjoyed great popularity at Charles I's court ("While Lydia I was loved by thee/Nor any was preferred 'fore me/To hug thy whitest neck...”; 2013, vol. I, p. 66). As noted above, Hawkins overtly justifies the inclusion of the same ode in his volume by resorting to the argument of authority. It is perhaps more likely, however, that he aimed to offer his own version of the popular theme, thus setting his "moral" collection in direct competition with contemporary imitations of Horace at the English court.

Other variations on the carpe diem theme by court poets at the time would indeed include Edmund Waller's "Go, lovely rose" (also later set to music), or the famously sensuous piece by Thomas Carew, "A Rapture" (admittedly more Ovidian than Horatian in spirit; see Martindale, 1992, p. 198), which circulated widely in manuscript form in court circles in the 1630s before being denounced in Parliament as leading to "the disgrace of religion" and "the increase of all Vice" (Ruoff, 1957,pp. 61-62). Another of Carew's poems on the carpe diem theme is revealingly described as "A persuasion to love, by one of the court" in a manuscript collection compiled c. 1625 (Herrick, 2013, vol. II, p. 430). While in Horace's poetry, the epicurean carpe diem topic was not necessarily associated with sensual wantonness (see Martindale, 1997, 
p. 75), this was, however, the interpretation which such court poets adopted and made fashionable. The hedonistic recuperation of the Horatian precedent is precisely what Hawkins appears to react against when he excludes the famous carpe diem Ode 1.11 from this collection, and presents Ode 1.34 as a poem in which the poet precisely "repents" to have followed the "Epicurean sect" and thus neglected religion (Hawkins, 1625, p. 11). Together with the description of Ode 2.18 as one chastising "others who are wholly addicted to their desires," or the framing of Ode 3.4 as denouncing "the corrupt manners of that age," Hawkins's singling out of "the Epicurean sect" may read as a more or less overt condemnation of libertine court poets who recuperatedor indeed, manipulated-Horace's poetry in order to legitimize their own moral dissolution. Further instances of licentious Horatianism would indeed follow, with a 1649 volume by John Smith, entitled The Lyrick Poet, containing suggestively expanded versions of two epodes usually omitted for obscenity. ${ }^{4}$

The 1625 volume may thus be read in dialogical relation with contemporary libertine imitations of Horace circulating, or being composed, in English court circles. This is all the more significant as Hawkins was also translating at the time the multi-volume treatise of Catholic devotion, La Cour sainte, by the French Jesuit Nicolas Caussin. The first volume of Hawkins's English translation, The Holy Court, would actually be issued by the Jesuit presses at St Omer the very next year, 1626. A prominent figure at the French court of Louis XIII in the 1620 s, Caussin consecrates his treatise to the fostering of virtue among the nobility, his aim being precisely to create a "holy court," as opposed to one ruled by hedonistic corruption and libertine materialism. The backdrop to this publication was a climate of growing concern about the renewed influence of epicurean materialism in France. The movement was perceived as extremely widespread among the French social and intellectual elite: as the French theologian Marin Mersenne famously stated in his 1624 commentary on the Book of Genesis, atheist libertines could be counted by the tens of thousands in Paris alone (Kors, 2014, p. 30).

Caussin directly attacks this new strand of epicureanism in $L a$ Cour sainte. He repeatedly warns his readers against the example of "that swine, Epicurus" ("ce pourceau d'Epicure"; Caussin, 1653 [1624], p. 149), expressly denouncing those who excuse their "libertine" mores

4. Scodel (2010, p. 216) notes how an added line praises a young man's oversized "launce-staff." 
through philosophical argument: "ne vous contentant pas de faire en vos moeurs l'Epicure, vous voulez debiter votre libertinage, avec de la Philosophie" (ibid., p. 157). A whole section is even devoted to "the Epicurean Life," in which Caussin identifies the modern Epicures as "une secte d'Epicuriens raffinés" (ibid., p. 111)—a phrase later rendered by Hawkins as "a Sect of reformed Epicures" (Hawkins, 1634, p.121), in a revealing echo of his caption for Ode 1. 29 (on "the Epicurean Sect") in the 1625 Horace volume.

Caussin's denunciation of vice at court is effectively addressed in the very dedication of the treatise to the French King, Louis XIII. Caussin adroitly presents his monarch as the means chosen by divine providence to "sanctify" the kingdom of France by the example of his virtue and the strength of his rule ("votre Majesté, que Dieu a choisie pour sanctifier son Royaume par l'exemple de ses vertus, et par l'auctorité de ses Lois"; Caussin, 1653 [1624], sig. a4v). Tingeing his praise with oblique political warning, Caussin further notes that it would represent a "disorder of Nature" if subjects of such a virtuous head of state were allowed to let vice flourish in the body politic:

Cette raison doit agir d'une forte vigueur dans le coeur des Français: puisque ce seroit un desordre de nature, de voir sous un bon Roy de mauvais sujets planter le crime dans le regne des vertus, et faire à une teste d'or un corps de mortier, et des pieds d'argille. (ibid.)

Caussin's rhetoric is reproduced in Hawkins's 1626 translation, dedicated this time to the English consort Queen Henrietta Maria, sister to the original French dedicatee. Not only does Hawkins include a full translation of the original epistle to Louis XIII, but he offers a close imitation of it in his own dedication to Henrietta Maria. He portrays her as a paragon of virtue, stresses her connection to the King of France ("your Royall Brother," Hawkins, 1626, sig. *r), and underlines her potential political role as a virtuous influence on the English court:

It hath pleased God (as a singular favour to this Kingdome) to affoard us in your Majesty, a Pious Queene, who exemplarly maketh good, what diffusedly is here handled. [...]

Here shall a Holy Court be found, fairely delineated: nor can I see how it will be in the power of persons of best Eminence, to plead Ignorance, and pretend inability, they having such a Booke to direct them, and such a Queene to follow. 
Lead then with alacrity (most Sacred Majesty,) and may propitious Heaven, so prosper your holy Desires, that the Greatest may have Matter to imitate, and the whole Nation to admire. (sig. ${ }^{*} \mathrm{v}-{ }^{*} 2 \mathrm{r}$ )

These lines obviously conform to the rhetoric of praise usually displayed in dedications, in which patrons, real or potential, are commonly portrayed as perfect examples of virtue (see on this McCabe, 2016). Such rhetorical flourishes are even more commonplace when dealing with royal dedicatees. However, in a volume explicitly presented as a Jesuit publication ("by Nicolas Caussin, of the Society of Jesus," title page), Hawkins's mentions of the Queen's "piety," as well as his own self-identification as her "humble Beadsman," that is, at once, her protégé, and, more literally, one that prays for her (sig. *2r), tend to highlight their shared religious connection with the Society. Henrietta Maria was in fact known for bringing her French Jesuit confessors to England and keeping them in her household, much to the dismay of the majority of Protestant courtiers. She would later regularly be blamed for facilitating Jesuit plots at the English court and exerting undue influence upon the King (Britland, 2006, p. 193). From the perspective of Hawkins and other English recusants, her political agency was indeed counted upon as a way of advancing the Catholic cause - a point the translator seems to touch upon when urging the Queen to "lead [...] with alacrity," and wishing the fulfillment of her "holy Desires." Beyond the customary rhetoric of praise, Hawkins's emphasis on the Queen as a model of Catholic piety and virtue at court thus identifies his Holy Court as one of the most visible aspects of the translation programme designed by English Jesuits to furnish the Catholic nobility with spiritual, as well as political direction in these uncertain times for the recusant community.

One can now plainly see how the ideological encoding of Hawkins's 1625 translation may be linked to a wider project of cultural as well as religious reform of the English court through the influence of virtuous Catholics. Hawkins's prefatorial statements on "teaching Virtue to the modest" and denouncing moral corruption closely match those deployed, not only in Caussin's writings, but also in other translations dedicated to high-ranking Catholics. One may find similar tropes about the moral virtues that should shine at the English court in the dedication of Edward Walpole's 1629 translation from Richeome's Pèlerin de Lorette to Henrietta Maria, or again, in Henry Hawkins's 1632 version of La Serre's Pensées de la Mort, dedicated this time to 
the recusant courtier, Henry Nevill, Baron Bergavenny. To return to Thomas Hawkins and his 1625 Horace volume, it appears that even the liminal poems of praise by various friends and court connections may have played their part, even if they ostensibly focus on Hawkins's skill as a translator, not on his cultural and ideological agenda. Indeed, by advertising the literary quality of the translation, and displaying at the same time their own skills as Horatian court poets, Hawkins's Catholic friends seem bent to show that they can meet libertine court poets on their own ground-and, in so doing, promote the "purer fountains" of a virtuous, Catholic horatianism at the English court.

Whether Hawkins's project did indeed contribute to the bettering of court mores remains uncertain. We have little trace of its reception among seventeenth-century readers, aside from mentions made by subsequent translators of Horace. It is referenced, for instance, in Alexander Brome's preface to his 1666 miscellany, The Poems of Horace [...] rendered into English by several persons. Hawkins's translation appears in fact to have succeeded in capturing a certain readership in its time: it enjoyed three subsequent editions during the reign of Charles I. A reviewed and enlarged edition appeared in 1631. The third and fourth editions were published in a bilingual format in 1635 and 1638, respectively, with the name of the translator finally displayed in full on the title page of the 1638 volume. The additions made in the later publications are highly suggestive of Hawkins's cultural agenda, as even a cursory examination may reveal. In the 1631 edition, Hawkins (or his publisher, William Lee), expressly directs the reader to the new contents of the collection, in a note placed after the liminal poems of praise reproduced from the first edition: "Reader, this Asterisce will direct thee to the odes newly inserted in this second Edition" (Hawkins, 1631, sig. A6v; see Figure 4). As could be expected, the additions do not include any love poems, or variations on the carpe diem theme. Instead, the "newly inserted" odes tend to confirm Hawkins's presentation of Horace as a moral poet, with, for example, the addition of Ode 1.3 "against the boldnesse or rashnesse of many" (Hawkins, 1631, p. 6). Hawkins also draws attention to his literary ambitions by including a self-reflective translation of Ode 4.2, revealingly captioned "It is dangerous to imitate ancient Poets" (ibid., p. 65). This addition cannot but be read as a response to Ben Jonson's famous "Ode to Himself," a close imitation of Horace's precedent written in reaction to the poor reception of the 1629 play, The New Inn, and first printed in 1631 (see on this Steggle, 1998). 


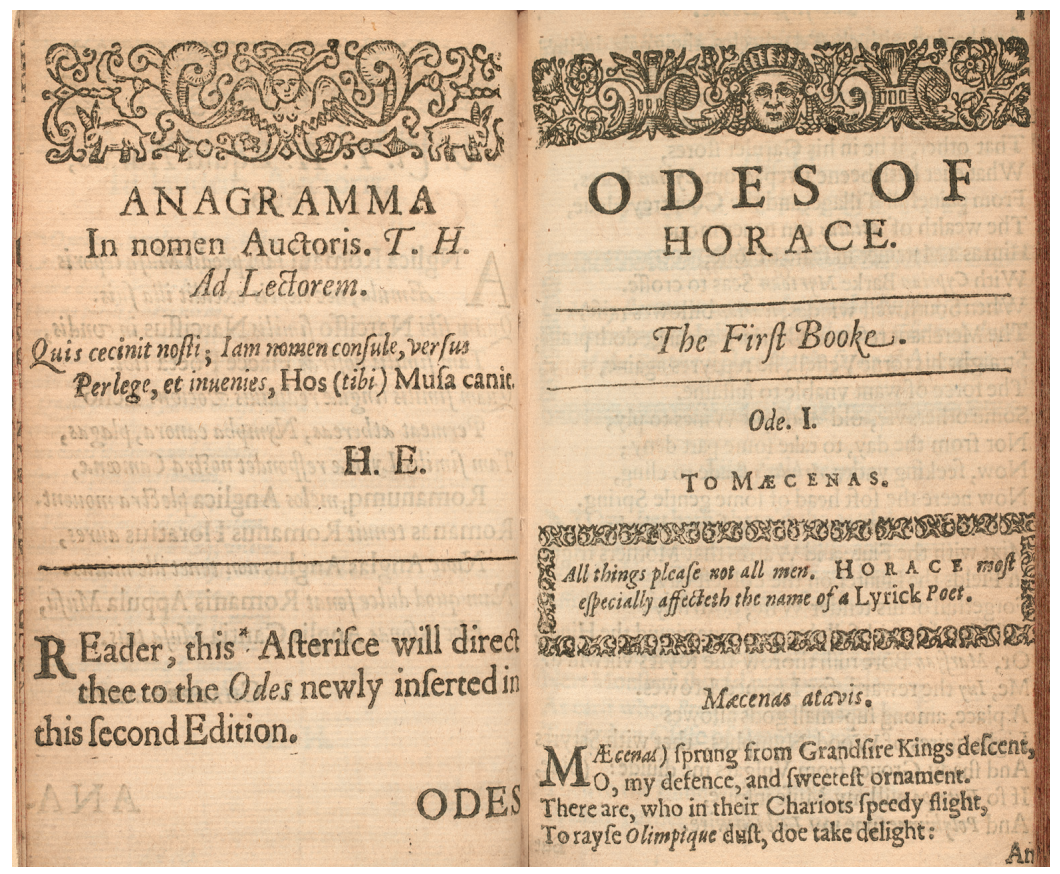

Figure 4. Odes of Horace, the best of lyrick poets contayning much morallity and sweetnesse. Selected, translated and in this edition reviewed, and enlarged with many more by Sr. T. H. London, William Lee, 1631, sig. A6v. Reproduced by permission of The Huntington Library, San Marino, California, Shelf $n^{\circ}: 28946$.

The majority of the added poems, however, convey a distinctly political colour to the volume. Odes 1.12, 3.5, and 4.14 are presented as "praises of Augustus"-a theme that was already present in the 1625 collection, as naturally befitting a publication issued on the year of Charles I's accession to the throne. Yet in 1631, the new praises are tinged with a degree of political anxiety, as disclosed by the titles given to Odes 1.14 ("To the Common wealth preparing afresh for Civill Warre"; Hawkins, 1631, p.11) or 2.1 ("advis[ing] to intermit the writing of Tragedies a while, till the Common-wealth be composed," ibid., p. 21). No less revealing is the inclusion, at the end of the volume, of the Carmen Seculare, here presented as "verses pronounced for the safety of the Romane Empire" (ibid., p. 96). The focus on the dangers of civil war is most probably related to the context of domestic unrest 
marking the years directly leading to the publication. Unusually poor harvests in 1629 and 1630 led to widespread social riots across England, including in the streets of London. These uprisings, first provoked by the soaring price of grain, at a time when England's involvement in Continental conflicts hindered imports, soon led to parliamentary unrest, which was in turn perceived as a challenge to Charles I's increasingly centralized power (Sharpe, 1995, pp. 463-464; 1978 , pp. $245 \mathrm{ff}$.). In this context, Hawkins's clearly signalled additions to the volume - a collection still encoded as a product of Catholic court circles by the inclusion of the original liminal poems-may be read as a commentary on the events, and a mark of support for Charles's rule on the part of Hawkins and his recusant friends.

Such support must have gained an additional, keener resonance in the fourth edition of the volume, published in 1638. This was a time when the religious reform imposed upon Scotland in 1637 by the Archbishop of Canterbury, William Laud, had just been met with popular rioting, as well as strong political opposition on the part of the Presbyterian Scottish nobility. Their challenge to royal authority, expressed in the Scottish "National Covenant," and the ensuing "Bishops' Wars" (1639-1640), have often been identified as one of the main factors leading to the English Civil Wars and to Charles I's eventual beheading (Sharpe, 1995, pp.785 ff). The attitudes of English Catholics in the conflict with Scotland were far from being unanimous, and it is difficult to infer Hawkins's own position in the matter. Still, his renewed expressions of loyalty towards Charles I in the 1638 edition of the Odes align his work with a growing corpus of Classical translations produced in the entourage of the King, drawing on the example and authority of ancient poets to give political advice, or safeguard royal power against the onslaughts of the "illiterate multitude." ${ }^{5}$ Consistently presented as a literary project, and overtly published under the aegis of "lyrica poesis" and literary "imitatio," Hawkins's Catholic Horace thus never ceases to be political. ${ }^{6}$

5. See on this Patterson (1984, pp. 172-176), Potter (1989, pp. 52-53 and pp. 89-90), Venuti (1995, pp. 44-57), and Norbrook (2000, pp. 65-66).

6. A last, posthumous edition of Hawkins's translated Odes would be published by William Webb in 1652, after the death of Charles I in 1649 and the final defeat of the Royalist party in 1651. Although Hawkins's agency is no longer at work here, it is clear that Webb's volume was designed to join the ranks of Royalist Classical translations published by former members of the Caroline court, such as John Denham, Sidney Godolphin, Richard Fanshawe, and others. 
The case of Hawkins's Odes of Horace and its various editions through the reign of Charles I offers an eloquent example of the ways in which, to quote again from Lefevere's work, "the process of translating and rewriting works of literature manipulates them to ideological and artistic ends, so that the rewritten text can be given a new [...] historical or literary status" (2016 [1992], back cover). Hawkins draws upon Horace's authority as a poetical model, a moral philosopher, a court poet, and an authority on literary translation, not only to establish his own cultural and social capital, but also to promote his particular cultural, religious, and political perception of the place and influence of (Catholic) poets and translators at the English court. Responding in an extremely astute manner to the fluctuating cultural and religious politics of the Caroline era, Hawkins's translation strategies confirm one of the most valuable intuitions of systems-based approaches: the necessity of studying the production and circulation of translated literature as closely interconnected with the social, material, ideological, and political contexts that surround, and to a certain extent, determine, specific translation features and strategies (see Hermans, 1999, p. 33 on the seminal importance of the "manipulation" group in that respect).

That being said, the very complexity of a case such as Hawkins's translation, in which literary aesthetics, moral philosophy, religious affiliations, and court politics are closely intermeshed, clearly illustrates the necessity of expanding and updating the original text- and systems-oriented methodology. One cannot overemphasize here the importance of examining the whole range of generic, ideological, material, and social codes involved in the manipulation of the literary text. Certainly, Lambert and Van Gorp's original descriptive model has helped uncover how Horace's text and cultural authority were appropriated and "refracted" at the preliminary, textual, meta-textual, and intertextual levels (involving, respectively: strategies of inclusion and exclusion; translation strategies; discursive strategies; relationships with contemporary productions of Stuart literary culture). Yet these textual, or discursive features cannot in turn be dissociated from the complex material, visual, and social languages of the early printed book. In terms of the material aspects of the translated book, elements such as illustrated title pages, captions, marginal annotations, printer's notes, and even mise-en-page all play a crucial part in Hawkins's re-working of Horace's poems according to his cultural agenda. As 
Guyda Armstrong has recently argued, such translations should thus be approached from a multi-modal perspective, in which literary and discursive codes are to be considered as interacting with other modes of cultural encoding within the economy of the printed text (Armstrong, 2015; see also Coldiron, 2015a and 2015b).

In fact, the social codes embedded in the printed book are just as important as its visual and material features. Laudatory verse such as the various encomia by Hawkins's friends have already been studied in terms of the development of seventeenth-century translation norms (see notably Hermans, 2014b [1985]). They have also been read as part of a developing discourse of social and cultural exclusion in Caroline court circles (see e.g., Venuti, 2018 [1995], pp. 36-37). Yet in this particular case, the identification of the various authors of liminal poems and their connections to English recusant networks at the English court and abroad have been crucial in order to decipher Hawkins's ideological and political stance. His moralizing discourse, which could otherwise have been interpreted as merely conforming to usual prefatorial commonplaces, takes a much more pointed significance when related to the practices and aspirations of the social, religious, and political network displayed in the liminal pages of the translation.

This, in turn, at once confirms and broadens recent calls among the Translation Studies community to adopt a network-oriented approach to the historical study of translations. As early as 1998, Anthony Pym stressed the importance of tracing networks of translators and text production when studying medieval, or nineteenthcentury translation practices and trends (pp.91-105). More recently, Şehnaz Tahir Gurçaglar has argued that focusing on networks of print production and dissemination offered a refreshing, and more historically accurate alternative to the somewhat partial and static view afforded by systems-based theories and methodologies (2007, p. 727). Tahir Gurçaglar had in mind, not only the limits of polysystems-based descriptions, but also those of some sociological approaches viewing translators and their activities in terms of class-determined "habitus," and the dynamics of the literary "field" (see also on this Folaron and Buzelin, 2007). One of the most significant complements to systemand field-based sociology has indeed been Hélène Buzelin's Latourian focus on "actor-networks" (2005), yielding fine-grained descriptions of translation as a multifaceted process, involving a variety of human, institutional, as well as commercial and material "actors." 
My perspective is slightly different here, in that it studies the human, institutional and material "assemblages" manifested in the early modern printed translation from a historiographical, not sociological, perspective. Still, the case of Hawkins's translated Odes suggests that the reconstruction of social and ideological networks, as revealed by a close reading of paratextual features and by a micro-historical focus on individual agents and specific time frames (here, the years 1625, 1630-1631, 1637-1638), can also significantly enrich and refine our understanding of the manipulation of translated literature in response to translators' personal agendas, as well as broader cultural trends and historical events.

What the multi-modal, multi-vocal approach I have sought to outline here finally reveals is the importance of continuing to expand our investigations of intertextual and contextual connections beyond the logic of translation norms, dominant ideology, patronage, and literary systems, which have been the usual focus of the "cultural" approach. Hawkins's exclusive and competitive strategies, aiming to turn Horace into a moral, Catholic-friendly, court poet alter ego, bear witness to aesthetic, religious, and ideological rifts between participants in a shared literary culture. Hawkins and his "libertine" competitors are indeed all recipients of the same literary heritage (Horace). They also share translation norms (free translation, or "imitation"), enjoy a common patronage system (the English court), and all hold an advantageous position in the literary field (as court poets imitating a major Classical text). Reading Hawkins's translation in terms of dominant literary and translation norms, or in sole relation to the Caroline patronage system and literary field, would simply efface its singularity. Instead, it is by paying attention to the complex language of social and ideological belonging - as fashioned in Catholic circles at the English court, and in the Anglo-French Jesuit network of translation and print circulation-that one can recognize the unique significance of what could otherwise be considered a minor work to the cultural politics of translation in seventeenth-century England.

\section{References}

Adolph, Antony R. J. S. (2004). "Hawkins, Sir Thomas (bap. 1575, d. 1640?)."

The Oxford Dictionary of National Biography. [https://doi.org/10.1093/ ref:odnb/12681].

Arber, Edward, ed. (1877). A Transcript of the Registers of the Company of Stationers of London, 1554-1640, vol. 4. London, Stationers' Company.

Armstrong, Guyda (2007). "Paratexts and their Functions in Seventeenth- 
Century English Decamerons." The Modern Language Review, 102, 1, pp. 4057.

Armstrong, Guyda (2015). "Coding Continental: Information Design in Sixteenth-Century English Vernacular Language Manuals and Translations." Renaissance Studies, 29, 1, pp. 78-102.

Ashmore, John, tr. (1621). Certain Odes of Horace. London, Humphrey Lownes for Richard Moore.

Bassnett, Susan (1998). "When is a Translation Not a Translation?" In S. Bassnett and A. Lefevere, Constructing Cultures: Essays on Literary Translation. Clevedon, Multilingual Matters, pp. 25-40.

Bassnett, Susan and André Lefevere, eds. (1990). Translation, History, and Culture. London, Pinter.

Bassnett, Susan and André Lefevere (1998). Constructing Cultures: Essays on Literary Translation. Clevedon, Multilingual Matters.

Bastin, Georges L. (2010). "Traduction et histoire. Les indispensables paratextes." In J. C. de Miguel, C. Hernández Sacristán and J. Pinilla, eds. Enfoques de teoría, traducción y didáctica de la lengua francesa [Perspectives sur la théorie, la traduction et la didactique de la langue française]. Hommage à Brigitte Lépinette. València, Universitat de València, pp. 47-60.

Bellany, Alastair (2002). The Politics of Court Scandal in Early Modern England: News Culture and the Overbury Affair, 1603-1660. Cambridge, Cambridge University Press.

Belle, Marie-Alice (2014). "At the Interface between Translation History and Literary History: A Genealogy of the Theme of 'Progress' in SeventeenthCentury English Translation History and Criticism." The Translator, 20, 1, pp. 44-63.

Belle, Marie-Alice (2017a). "Rhetorical Ethos and the Translating Self in Early Modern England.” In A. Rizzi, ed. Trust and Proof. Translators in Early Modern Print Culture. Leiden/Boston, Brill, pp. 62-84.

Belle, Marie-Alice (2017b). "Autour de la question des 'communautés de lecteurs': Discours liminaire et amicitia horatienne chez Jonson et ses contemporains." In L. Cottegnies, N. Dauvois and B. Delignon, eds. Horace et l'invention de la vie privée. Paris, Classiques Garnier, pp. 359-380.

Belle, Marie-Alice and Brenda M. Hosington (2017). "Translation, History, and Print: A Model for the Study of Printed Translations in Early Modern Britain." Translation Studies, 10, 1, pp. 1-21.

Belle Marie-Alice and Brenda M. Hosington, eds. (2018). Thresholds of Translation: Paratexts, Print, and Cultural Exchange in Early Modern Britain (1473-1660). Cham [Switzerland], Palgrave Macmillan.

Boro, Joyce (2018). "Spain in Translation: Peritextual Representations of Cultural Difference, 1614-1625.” In M.-A. Belle and B. M. Hosington, eds. Thresholds of Translation: Paratexts, Print, and Cultural Exchange in Early Modern Britain. Cham [Switzerland], Palgrave Macmillan, pp. 101-134.

Britland, Karen (2006). Drama at the Courts of Queen Henrietta Maria. 
Cambridge, Cambridge University Press.

Burrow, Colin (2004). "Holland, Hugh (1563-1633)." The Oxford Dictionary of National Biography. [https://doi.org/10.1093/ref:odnb/13527].

Buzelin, Hélène (2005). “Unexpected Allies. How Latour's Network Theory Could Complement Bourdieusian Analyses in Translation Studies." The Translator, 11, 2, pp. 193-218.

Cary, Elizabeth (1994 [1613]). The Tragedy of Mariam, Queen of Jewry, with The Lady Falkland, Her Life, By One of her Daughters, ed. Barry Weller and Margaret W. Ferguson. Berkeley, University of California Press.

Caussin, Nicolas (1624). La Cour sainte, ou l'institution chrestienne des grands, avec les exemples de ceux qui dans les cours ont fleury dans la saincteté, par le $R$. P. Nicolas Caussin. Paris, S. Chappelet.

Caussin, Nicolas (1653). La Cour sainte, du R. Pere Nicolas Caussin de la Compagnie de Jésus. Paris, D. Béchet.

Coldiron, Anne E. B. (2012). "Visibility Now: Historicizing Foreign Presences in Translation." Translation Studies, 5, 2, pp. 189-200.

Coldiron, Anne E. B. (2015a). Printers Without Borders: Translation and Textuality in the Renaissance. Cambridge, Cambridge University Press.

Coldiron, Anne E. B. (2015b). "Form(e)s of Transnationhood. The Case of John Wolfe's Trilingual Courtier.” Renaissance Studies, 29, 1, pp. 103-124.

Denham, John (1647). "To the Author of this Translation." In R. Fanshawe, tr. Il Pastor Fido. The Faithful Shepherd. Written in Italian by Battista Guarini, a Knight of Italie. And Newly Translated out of the Originall. London, Richard Raworth, sig. (a)r-v.

Folaron, Debbie and Hélène Buzelin (2007). "Connecting Translation and Network Studies.” Meta, 52, 4, pp. 605-642.

Foley, Henry, ed. (1878). Records of the English Province of the Society of Jesus, vol. 4. London, Burns and Oates.

Genette, Gérard (1987). Seuils. Paris, Seuil.

Genette, Gérard (2001 [1987]). Paratexts: Thresholds of Interpretation. Trans. Jane E. Lewin. Cambridge, Cambridge University Press.

Gil Bardaji, Ana, Pilar Orero and Sara Rovira Esteva, eds. (2012). Translation Peripheries. Paratextual Elements in Translation. Bern, Peter Lang.

Hawkins, Henry, tr. (1632). The sweete thoughts of death, and eternity. Written by Sieur de la Serre. Paris [i.e. St Omer, English College Press].

Hawkins, Thomas, tr. (1625). Odes of Horace, the best of Lyrick Poets, Contayning much morality and sweetnesse. Selected and Translated by Sir T[homas] $H$ [awkins]. London, William Lee.

Hawkins, Thomas, tr. (1626). The Holy Court. Or the Christian institution of men of quality. With examples of those, who in court have flourished in sanctity. By Nicolas Caussin of the Society of Iesus. Written in French, E translated into English by T. H. Paris [i.e. St Omer, English College Press].

Hawkins, Thomas, tr. (1631). Odes of Horace, the best of lyrick poets contayning much morallity and sweetnesse. Selected, translated and in this edition reviewed, 
and enlarged with many more by Sr. T. H. London, William Lee.

Hawkins, Thomas, tr. (1634). The boly court in three tomes. VVritten in French by Nicolas Caussin, S.I. Translated into English by Sr. T. H. and dedicated to the Queene of Great Brittaine. [Rouen], John Cousturier.

Hawkins, Thomas, tr. (1635). Odes of Horace. The best of lyrick poets. Containing much moralitie and sweetnesse. The third edition. Selected, translated, reviewed, and enlarged with many more. By Sr. T. H. London, William Lee.

Hawkins, Thomas, tr. (1638). Odes of Horace, the best of lyrick poets. Containing much morality and sweetnesse. The fourth edition. Selected, translated, reviewed, and enlarged with many more, by Sr. T. H. London, William Lee.

Hawkins, Thomas, tr. (1652). Horace, the best of lyrick poets. Containing much morality, and sweetnesse. Together with Aulus Persius Flaccus bis satyres. Translated into English by Barten Holyday somtime student of Christ-Church in Oxford. London, William Webb.

Hermans, Theo (1999). Translation in Systems. Description and System Oriented Approaches Explained. Manchester, St. Jerome.

Hermans, Theo, ed. (2014a [1985]). The Manipulation of Literature: Studies in Literary Translation. Amsterdam, Croom Helm.

Hermans, Theo (2014b [1985]). "Images of Translation: Metaphor and Imagery in the Renaissance Dicourse on Translation." In T. Hermans, ed. The Manipulation of Literature: Studies in Literary Translation. Amsterdam, Croom Helm, pp. 103-135.

Herrick, Robert (2013). The Complete Poetry, ed. T. Cain and R. Conolly. 2 vol. Oxford, Oxford University Press.

Horace [Quintus Horatius Flaccus] (2004). Odes and Epodes, ed. and tr. Niall Rudd. Loeb Classical Library, vol. 33. Cambridge, Harvard University Press.

Hosington, Brenda M. (2017). "Collaboration, Authorship, and Gender in the Paratexts Accompanying Translations by Susan Du Verger and Judith Man." In P. Pender, ed. Gender, Authorship, and Early Modern Women's Collaboration. Cham [Switzerland], Palgrave Macmillan, pp. 95-121.

Kennedy, Ross (2004). "Fortescue, George (c. 1588-1659)." The Oxford Dictionary of National Biography. [https://doi.org/10.1093/ref:odnb/9941].

Kors, Alan Charles (2014). Atheism in France, 1650-1729, Volume I: The Orthodox Sources of Disbelief. Princeton, Princeton University Press.

Lambert, José (2006 [1995]). "Translation, Systems, and Research: The Contribution of Polysystems Studies to Translation Studies." In L. D'hulst, D. Delabatista and R. Meylaerts, eds. Functional Approaches to Culture and Translation: Selected Papers by José Lambert. Amsterdam, John Benjamins.

Lambert, José and Hendrik Van Gorp (2014 [1985]). "On Describing Translations." In T. Hermans, ed. The Manipulation of Literature: Studies in Literary Translation. Amsterdam, Croom Helm, pp. 42-53.

Lefevere, André (1984). "On the Refraction of Texts." In M. Spariosu, ed. Mimesis in Contemporary Theory, vol. 1. Amsterdam, John Benjamins, pp. 217-237. 
Lefevere, André (1988). "Holy Garbage, Tho' by Homer Cook't." TTR, 1, 2 , pp. 19-27.

Lefevere, André (1998). "Translation Practice(s) and Cultural Capital. Some English Aeneids." In S. Bassnett and A. Lefevere, Constructing Cultures: Essays on Literary Translation. Clevedon, Multilingual Matters, pp. 41-56.

Lefevere, André (2016 [1992]). Translation, Rewriting, and the Manipulation of Literary Fame. London and New York, Routledge.

Martindale, Charles (1992). "Horace, Ovid, and Others." In R. Jenkyns, ed. The Legacy of Rome. A New Appraisal. Oxford, Oxford University Press, pp. 177-214.

Martindale, Joanna (1997). "The Horace of Ben Jonson and his Heirs." In D. Hopkins and C. Martindale, eds. Horace Made New. Horatian Influences on British Writing from the Renaissance to the Twentieth Century. Cambridge, Cambridge University Press, pp. 50-85.

McCabe, Richard A. (2016). "Ungainefull Arte." Poetry, Patronage, and Print in the Early Modern Era. Oxford, Oxford University Press.

Moul, Victoria (2010). Jonson, Horace, and the Classical Tradition. Cambridge, Cambridge University Press.

Norbrook, David (2000). Writing the English Republic. Rhetoric and Politics, 1627-1660. Cambridge, Cambridge University Press.

Patterson, Annabel (1984). Pastoral and Ideology. Virgil to Valéry. New Haven, Yale University Press.

Pellat, Valerie, ed. (2013). Text, Metatext, Extratext, and Paratext in Translation. Cambridge, Cambridge Scholars Press.

Pierce, R. B. (1981). "Ben Jonson's Horace and Horace's Ben Jonson." Studies in Philology, 78, pp. 20-31.

Potter, Lois (1989). Secret Rites and Secret Writing. Royalist Literature, 16411660. Cambridge, Cambridge University Press.

Pym, Anthony (1998). Method in Translation History. Manchester, St. Jerome.

Rider, Henry, tr. (1638). All the Odes and Epodes of Horace. Translated into English verse: by Henry Rider, Master of Arts of Emmanuel Colledge in Cambridge. London, John Haviland, for Robert Rider.

Ruoff,J. E. (1957). “Thomas Carew's Early Reputation.” Notes and Queries, 202, pp. 61-62.

Ryan, Anthony Charles (2004). "Hawkins, Henry (bap. 1577, d. 1646)." The Oxford Dictionary of National Biography. [https://doi.org/10.1093/ ref:odnb/12669].

Saenger, Michael (2006). The Commodification of Textual Engagements in the English Renaissance. Aldershot, Ashgate.

Scodel, Joshua (2010). "Non-Dramatic Verse: Lyric." In G. Braden, R. Cummings and S. Gillespie, eds. The Oxford History of Literary Translation into English, Volume 2:1550-1660. Oxford, Oxford University Press, pp. 212-47.

Sell, Roger D. (2004). "Beaumont, Sir John, first baronet (1584-1627)." 
The Oxford Dictionary of National Biography. [https://doi.org/10.1093/ ref:odnb/1874].

Sharpe, Kevin, ed. (1978). Faction and Parliament. Essays on Early Stuart History. Oxford, Clarendon Press.

Sharpe, Kevin (1995). The Personal Rule of Charles I. New Haven, Yale University Press.

Smith, Helen and Louise Wilson, eds. (2011). Renaissance Paratexts. Cambridge, Cambridge University Press.

Solt, Leo (1990). Church and State in Early Modern England (1509-1640). Oxford, Oxford University Press.

Steggle, Matthew (1998). "Valeatres ludicra: An Imitation of Horace in Jonson's 'Ode to Himself'.” Ben Jonson Journal, 5, pp. 101-113.

Steggle, Matthew (1999). "Horace the Second, or Ben Jonson, Thomas Dekker, and the Battle for Augustan Rome." In P. Franssen and A. J. Hoenselaars, eds. The Author as Character: Representing Historical Writers in Western Literature. Madison, Fairleigh Dickinson University Press, pp. 118-130.

Tahir-Gürçağlar, Şehnaz (2002). "What Texts Don't Tell. The Uses of Paratexts in Translation Research.” In T. Hermans, ed. Crosscultural Transgressions. Research Models in Translation Studies II. Historical and Ideological Issues. Manchester, St. Jerome, pp. 44-60.

Tahir-Gürçağlar, Şehnaz (2007). "Chaos Before Order: Network Maps and Research Design in DTS.” Meta, 52, 4, pp. 724-743.

Toury, Gideon (1995). Descriptive Translation Studies and Beyond. Amsterdam, John Benjamins.

Tymoczko, Maria (2005). "Trajectories of Research in Translation Studies." Meta, 50, 4, pp. 1082-1097.

Tymoczko, Maria (2007). Enlarging Translation, Empowering Translators. Manchester, St. Jerome.

Venuti, Lawrence (2004). "Retranslations: The Creation of Value." Bucknell Revierw, 24, 1, pp. 25-38.

Venuti, Lawrence (2018 [1995]). The Translator's Invisibility. A History of Translation. London and New York, Routledge.

Walpole, Edward, tr. (1629). The Pilgrim of Loreto. Performing his vow made to the glorious Virgin Mary Mother of God. Conteyning diuers deuout meditations vpon the Christian and Cath. doctrine. By Fa. Lewis Richeome of the Society of Iesus. Written in French, E translated into English by E.W., Printed at Paris [i.e. Saint-Omer, English College Press].

Marie-Alice Belle

Département de linguistique et de traduction

Université de Montréal

Montréal (Québec), Canada marie-alice.belle@umontreal.ca 